\title{
Developing a Global Citizenship Education Programme for Three to Six Year Olds
}

Rowan Oberman St Patrick's College, Drumcondra, Ireland Fionnuala Waldron St Patrick's College, Drumcondra, Ireland Sheila Dillon Education Officer, Trócaire, Ireland

\begin{abstract}
This article outlines the development of a global citizenship education programme for three to six year olds. The programme, entitled Just Children, was created by Education for a Just World, a partnership between an Irish Development Non-Governmental Organisation (DNGO), Trócaire, and the Centre for Human Rights and Citizenship Education located in St Patrick's College, Drumcondra, Dublin. ${ }^{1}$ The programme was developed through three phases of research. The first phase examined young children's engagement with global justice issues; the second phase explored possible strategies for including global citizenship education in early childhood educational settings; and the third phase tested a draft global citizenship education programme. This article explores the key principles integral to educating for and about global justice and, responding to the results of research as well as the early childhood education landscape, arrives at strategies for introducing global justice work into early childhood settings. This article suggests that introducing a global perspective into early childhood education, using open-ended and active methodologies, supports the development of global citizenship skills, attitudes and understanding.
\end{abstract}

Keywords: early childhood, empathy, essentialism, fairness, global citizenship, postcolonialism, poverty, stereotype, resource development

\section{Introduction}

Global citizenship education promotes understanding of global issues; it encourages critical engagement with those issues and is cognisant of their complexity; it addresses the culpability of western countries in global poverty; and supports local responsibility for global concerns (Andreotti, 2006; Oxfam, 2006; Bryan, 2008; Davies, 2006; Krause, 2010). As an education in poverty, complexity and culpability, the suitability of global citizenship education for early childhood education may be perceived by educators as problematic and its application here extremely challenging. However research indicates that children begin to develop prejudices relating to 
gender and race (Ruble and Martin, 1998) as well as conceptions of fairness and a capacity for empathy (Killen, Breton, Ferguson and Handler, 1994; Killen and Smetana, 1999; Tisak 1995 cited in Killen et al, 2001) from a young age. Furthermore, as this article will argue, if global citizenship education in primary and secondary schools is to achieve a level of complexity and deeper understanding it needs to be more than an occasional and media driven learning 'stir in' (Bracken and Bryan, 2010), with learning being scaffolded from an early age.

This paper sets out a response to the question of how to begin global citizenship education with young children in ways that are appropriate, that contribute to the development of global citizenship skills, attitudes and knowledge and that use suitable, empowering and learner centred pedagogy.

\section{Theoretical Framework Global Citizenship Education}

Global citizenship education, which, for the purposes of this article, could also be referred to as global education or development education (Bryan et al, 2009; Krause, 2010) is concerned with understanding the causes and consequences of injustice and inequality in the world and in encouraging action to effect social change (Bryan et al, 2009; Oxfam, 1997; Davies, 2006; Krause, 2010; Fiedler et al, 2008). While approaches to and conceptions of global citizenship education vary, there is relative consensus that it involves the development of attitudes, dispositions and skills, as well as knowledge about the unequal distribution of wealth, life chances and power, about connections between wealth and poverty, progress and inequality, and about international relations. Further, it is broadly accepted that these educations encompass core components which include the relationship between the developing and developed world, critical thinking and personal reflection and that pedagogies are interactive and active (Fiedler et al, 2008; Regan, 2006; Pike and Selby, 2000; Hicks, 2003; Case, 1993; Oxfam, 2006; Krause, 2010).

Approaches to global citizenship education can vary across a range of dimensions, including levels of engagement with issues of power, openness to critical thinking and ideas of causality and culpability. At one end of the continuum are those approaches that prioritise 'soft' global citizenship education, focussing on respect for cultural differences, recognition of the effects of poverty and the promotion of global solidarity. At the other end of the continuum a 'critical' approach to global citizenship education highlights the importance of a post-colonial framework in exploring development issues (Andreotti, 2006; Bryan, 2008). This approach characteristically emphasises the asymmetrical power relations between the global North and the global South, along with the global North's dominance in shaping systems (economic, belief, cultural and others). It encourages the learner, rather than empathising with others, to 'recognise oneself as implicated in the social forces that create the climate of obstacles the other must confront' (Boler, 1997:257). It priori- 
tises open ended self-reflection over more didactic messages, thereby establishing moral obligations to act (Andreotti, 2006:48). Evident within these different approaches to global citizenship education are two conceptions of justice/injustice within a development education context - one which focuses on the unequal distribution of goods per se, and the other which emphasises the causes of that unequal distribution. Education approaches which appeal to the learners' humanitarian principles and present poverty as a 'lack' to which we are morally obliged to respond, explore justice from the perspective of global inequality. The world is unjust because of the stark unequal distribution of resources and opportunity; it is unjust because some have while others have not. The critical approach to global citizenship education emphasises the 'chains of cause and effect' between the wealthy's wealth and the poor's poverty, the powerful's power and the powerless' powerlessness. It encourages a responsibility to act based on culpability.

\section{Young Children}

Educating for global justice involves complex and emotive issues which present challenges in an early childhood education context. Firstly, one might question the appropriateness of exposing young children to such political and sensitive issues. Secondly, if it is appropriate, making issues of global justice accessible to young children remains a challenge (Husband, 2010).

The literature related to young children's engagement with issues of global justice reveals conflicting attitudes regarding children's perceived 'readiness' to deal with global justice questions (Robinson and Jones Diaz, 2009; Kelly and Brooks, 2009). Traditional perspectives construct children as being too young and too innocent to engage with 'adult' issues. However, new ways of thinking about and understanding childhood and children's learning have emerged from socio-cultural theory, postmodern/poststructuralist theories and from critical psychology (Robinson and Jones Diaz, 2009; Devine, 2003; Hong, 2003). Proponents of these new perspectives challenge conventional fixed definitions of childhood such as Piaget's (1932) theory of cognitive-development, ${ }^{2}$ the perception of children as passive recipients of the dominant culture and many of the traditional universalised 'truths' about 'the child' which underpin modernist perspectives (Robinson and Jones Diaz, 2009; Devine, 2003). Moreover, postmodernist/poststructuralist theories of childhood offer a counterpoint to modernist discourses of childhood innocence and to the idea that children are intrinsically different from adults (Kelly and Brooks, 2009; Robinson and Jones Diaz, 2009).

While traditional theories of child development continue to exert a strong influence on whether social justice education occurs in early childhood settings in Ireland at the level of practice, essentialised and deficit perspectives on children's capacities are increasingly challenged by the neo-Vygotskian and Brunerian approaches to children's learning which have been embedded in curriculum policy since the 
1990s. Bruner's view that 'any subject can be taught effectively in some intellectually honest form to any child at any stage of development' (Bruner, 1960:33), for example, suggests that rather than seeing global justice issues as outside of the understanding of young children, educators should work at making complex ideas accessible in age-appropriate ways. Given the evidence which suggests that young children are already constructing racialised, discriminatory and prejudiced world-views by the time they come to school, there is a strong imperative towards including global justice education in early childhood contexts (Ramsey, 2008a; Connolly and Hosken, 2006; Brooker, 2006; Robinson and Jones Diaz, 2009). Furthermore, existing research in the area of young children's constructions of fairness suggests their growing capacity to identify and articulate perceptions of injustice (Ramsey, 2008a; Ramsey, 2008b; Killen, Breton, Ferguson and Handler, 1994; Killen and Smetana, 1999; Tisak 1995 cited in Killen et al, 2001; Theimer et al, 2001 cited in Brown and Bigler, 2005). In an Irish context, the publication of Aistear: The Early Childhood Curriculum Framework (National Council for Curriculum and Assessment, 2009), exemplifies this trend towards recognising and building on children's capabilities and signals the potential for early childhood education to be a significant site of educational change. ${ }^{3}$ In putting in place a rubric for the education of children, from birth to six years, Aistear offers a road map for developing education programmes for young children. It acknowledges the changing nature of Irish society and values young children as citizens who actively engage in their own learning, with others, and in the world around them.

'Help me to learn to value social and cultural difference and to recognise that I live in a diverse, multi-ethnic society. Help me to learn to recognise and challenge injustice and discrimination and to stand up for myself and others.' (NCCA, 2009:7)

The Framework challenges educators to integrate a concern for social justice into their work. It does not suggest staggering children's learning by starting with the local and expanding outwards and as such raises the question of the extent to which young children should engage with issues of justice at both an immediate and global level.

\section{Methodology: Developing a Global Justice Programme}

The early childhood global citizenship programme, the subject of this paper, was developed through an extensive research process. Research was conducted in three phases with the purpose of informing and testing strategies for integrating global justice education into preschool and infant class settings. ${ }^{4}$ Between each research phase, a resource development team engaged in critical reflection on the results of the research and in the development of further materials for the next phase, ultimately resulting in the final education programme. During the later stages of the process the resource development team was advised by educationalists with different specialisms relating to early childhood education. The groups involved in 


\section{Table 1: Groups involved in the research and resource development} process

$\begin{array}{ll}\text { Resource Development Team: } & \begin{array}{l}\text { The resource development team comprised eight educationalists with } \\ \text { involvement in development education in Ireland. The team included members } \\ \text { of the development education section of the DNGO partner and members of the } \\ \text { Education Faculty of the third-level education partner. }\end{array} \\ \text { Advisory Committee: } & \begin{array}{l}\text { The advisory committee was comprised of fifteen educationalists specialising in } \\ \text { different areas of early childhood education pedagogy including: mathematics, } \\ \text { drama, art, educational disadvantage, geography, literacy, physical education, } \\ \text { history and special educational needs. }\end{array} \\ & \begin{array}{l}60 \text { children aged } 3 \text { to } 6 \text { years, educated in three settings, and their educators, } \\ \text { were involved in the first phase of the research. }\end{array} \\ \text { Educators } & \begin{array}{l}\text { Forty educators (pre-school and infant class teachers) drawn from schools and } \\ \text { preschools in the Republic of Ireland were engaged in phases two and/or three } \\ \text { of the research. }\end{array}\end{array}$

Table 2: Research and Resource Development Process

\begin{tabular}{|c|c|c|}
\hline Phase & Focus & Participants \\
\hline Research Phase 1 & $\begin{array}{l}\text { Explore young children's } \\
\text { engagement with issues of } \\
\text { of global justice }\end{array}$ & $\begin{array}{l}\text { Children between the ages of } 3 \text { and } 6 \text { years } \\
\text { Educators }\end{array}$ \\
\hline $\begin{array}{l}\text { Critical review and } \\
\text { resource development }\end{array}$ & $\begin{array}{l}\text { Critical review of the results of } \\
\text { research phase } 1 \text {, selection of } \\
\text { materials for phase } 2\end{array}$ & Resource Development Team \\
\hline Research Phase 2 & $\begin{array}{l}\text { Explore strategies for introducing } \\
\text { early childhood global citizenship } \\
\text { education }\end{array}$ & Educators \\
\hline $\begin{array}{l}\text { Critical review and } \\
\text { resource development }\end{array}$ & $\begin{array}{l}\text { Critical review of the results of } \\
\text { phase } 2 \text { and phase } 1 \text { of the } \\
\text { research. Development of draft } \\
\text { programme. }\end{array}$ & $\begin{array}{l}\text { Resource Development Team } \\
\text { Advisory Committee }\end{array}$ \\
\hline Research Phase 3 & Pilot draft programme. & Educators \\
\hline $\begin{array}{l}\text { Redrafting of Education } \\
\text { Programme }\end{array}$ & $\begin{array}{l}\text { Critical review of all results of } \\
\text { all phases of the research. } \\
\text { Redrafting of the programme. }\end{array}$ & $\begin{array}{l}\text { Resource Development Team } \\
\text { Advisory Committee }\end{array}$ \\
\hline $\begin{array}{l}\text { Final Review and } \\
\text { Amendments }\end{array}$ & $\begin{array}{l}\text { Education programme was } \\
\text { reviewed and amended. }\end{array}$ & $\begin{array}{l}\text { Educators } \\
\text { Resource Development Team }\end{array}$ \\
\hline
\end{tabular}

the research and resource development process are set out in Table 1. An overview of the research and resource development process is set out at Table 2. See Appendix A for a short description of the resource pack containing the programme.

\section{Research Phase One: Young Children's Engagement with Issues of Global Justice}

The first phase of the research had the primary objective of identifying how young children engage with issues of global justice. The research was undertaken in three settings: a pre-school class, a Junior Infant class and a Senior Infant class. Each setting was in a different social context at different locations around Ireland. 
The research was undertaken over a four week period. It involved a total of sixty children and four participating teachers. The research approach taken was qualitative, informed by the 'mosaic' approach (Clark and Moss, 2001) and drawn from existing classroom practices. The principal strategy used was adult-child interaction through dialogue. It involved observation and recording of children's engagement with materials presented by the teacher, and small group work facilitated by the researcher using Thinking Time/Circle Time, story, drama and the exploration of images. The educators were asked to give feedback on their own thoughts on the lessons and on the discussion with the children. The educators were also asked to note any impacts or talking points relating to the research topic which arose from the children in the days between each visit. Provision was also made for a follow-up interview with the participating educators.

As with all research involving young children, ethical issues relating to participants' consent, participation and beneficence arose here. Extensive efforts were made to communicate the purpose and the nature of the research to all participants and to ensure that consent was given both to engage in and remain participating in the research. The research methods used reflected efforts: to maximise access to the authentic voices of the children, to be in keeping with good educational practice offering substantial learning opportunities to the participants, and to incorporate the contribution of the participating children regarding research design.

\section{Research Phase Two: Exploring Strategies for Introducing Global Citizenship Education into Early Childhood Education}

The second phase of the research involved early childhood educators working in both preschool and primary school settings. The purpose of this phase of the research was to identify suitable strategies for and challenges to engaging young children in global citizenship eduction with the aim of deriving a draft educational programme. Twenty eight educators, located in four areas of Ireland, were involved in the research. The participant educators were introduced to the initial research (phase 1) and provided with suggested materials (these are set out below). They were not provided with a prescribed programme, although the key themes of global citizenship education were explored.

Participant educators were asked to record their use of the materials provided with the children, challenges they encountered and suggestions for the development of an early childhood global citizenship education programme. Data were collected through focus groups, participant structured diaries and from work completed by the participants' pupils' relating to the programme. All focus groups were recorded by the researchers. 
This qualitative participatory approach was adapted to the research as the purpose of the research was exploratory and to support programme development. Educator focus groups were used as sites for social learning (Wibeck et al, 2007) providing opportunities for the research to benefit from educator participants interacting and exchanging experiences (Wibeck et al, 2007; Myers, 1998).

\section{Materials}

Participants were provided with the colourful children's picture book Mama Panya's Pancakes (Chamberlin and Chamberlin, 2005). Set in Kenya, the story depicts the journey made by Adika and his mother to their local market to buy food to make pancakes. On their way Adika, despite his mother having just two coins, invites an increasing number of friends for pancakes. To Mama Panya's relief, the friends do not arrive at the pancake party empty handed, but with food and music for a feast.

Research participants were also provided with eight A3 photographs of a young girl, Cecelia, living in an informal settlement on the outskirts of Nairobi. The photographs depicted the girl at home with her parents, at pre-school, with friends and in her community.

\section{Research Phase Three: Piloting an Early Childhood Global Citizenship Education Programme}

The third phase of the research piloted the early childhood global citizenship education programme developed by the resource development team in response to the outcomes of phases one and two of the research, and in the context of the national curriculum framework. ${ }^{5}$ Close collaboration between the resource development team and the advisory committee ensured that the complex integration of learning for global citizenship into diverse curriculum areas reflected good early childhood educational practice, and promoted children's learning across the curriculum.

Participant educators in the third phase of the research were given further materials including: a puppet of the Adika character, additional stories involving the Adika and Cecelia characters, and the drafted global justice education programme as well as the photographs and storybook outlined above.

Twenty-four participant educators were involved in this phase of the research, half of whom had been involved in phase two of the research, half of whom were new to the project. All participants were educators in pre-schools or infant classes. Participants were introduced to the draft education programme, to key issues in global citizenship education and to the preceding research process. Participants were asked to record their use of the draft programme with their pupils and the children's learning they perceived. As with phase two, data were collected through focus groups, participant structured diaries and through the work of the participating children. 


\section{Data Analysis}

Data were analysed using a grounded theory approach (Glaser and Stauss, 1967). Data sources included interview data, field notes, journal entries and children's work. The data from each phase of the research were reviewed by members of the resource development team independently. Through close analysis of the data, emerging themes were identified for each phase of the research. Through discussion between team members key emerging themes and a corresponding coding system were agreed and then applied to the data. This process allowed issues and evidence of most interest under these themes to emerge.

\section{Results}

\section{Results of Phase One}

Phase one of the research provided an indication of young children's conceptions of global justice issues, factors which influence these conceptions, and strategies which might be developed to support young children's engagement with issues of global justice.

\section{Conceptions of Poverty and Fairness}

The findings suggest that young children's understandings of poverty and justice are emergent. For younger children it appears that there is a conceptual understanding of people not having enough. The older children involved in the research, showed a greater tendency to use terms such as 'poor' and 'rich'. Poverty was more consistently understood by all children as the denial of, or lack of basic needs rather than a lack of money. Although children in each setting had an understanding of the importance of money, this was more evident among older children. The previous experience of children was an important factor in their engagement with ideas of poverty and need. Their understanding of food and water as needs, for example, and their own familiarity with the concepts of hunger and thirst enabled them to engage with the materials provided. This concurs with the contention of Chafel et al (2007) that children are more actively engaged when they can incorporate their own personal experiences.

\section{Ability to Empathise}

Throughout the study and research settings there was ample evidence of the expression of feelings and emotions, concern and empathy for others. The children's capacity to empathise was evident in their ability to describe how characters in the story and photographs used might be thinking or feeling. Across the research settings, children expressed concern and empathy for others perceived by them to be in need. This appeared to be grounded in their personal experiences and based on familiar scenarios and contexts rather than on a larger global sense of justice and fairness. The findings are consistent with current post-structural theories of childhood which hold that children are capable of independent thinking, and agency and can understand issues beyond their own self-interest.

44 International Journal of Development Education and Global Learning 4(1) 2012 


\section{Stereotypical Conceptions of Africa}

While previous research has established that children can be influenced by racial stereotypes (Ruble and Martin, 1998; Connolly, 1998; Killen et al, 2001), this research highlights the extent to which very young children have begun to form stereotypical ideas of African countries and made associations between Africa and poverty. These ideas tended to dominate children's conceptions of African countries and African people even when they were exposed to positive images as part of the research process.

The importance of family experiences and the influence of the media were exemplified by a child whose family was subscribing to a child sponsorship scheme in Africa and whose parents had explained their rationale for doing so. Her description of life in Africa draws heavily on this rationale.

'In Africa, nobody can get no food, they have no sheep, no cows...we have to help the people in Africa'. (Pupil: Junior Infant class)

This highlights how child sponsorship schemes and the media provide some children with an awareness of the wider world. They may also instill an essentialist view that Africa is poor and we have the means and responsibility to provide solutions.

Most significantly, the research identified starting points to inform global citizenship education programmes for young children. The findings suggest young children have the capacity to engage with complex issues of justice and fairness when appropriate strategies and methodologies are used.

\section{Results of Phase Two}

The participant educators involved with the second phase of the research recorded a variety of activities done with their children as part of this research process. An analysis of the focus group meetings, the structured diaries and the pupils' work suggested that while all participants had used the story book and encouraged child engagement with the story, the degree to which they engaged children with issues of global justice varied considerably. Furthermore, the results also highlight the possibility of learning outcomes which were contrary to the programme's objectives.

From an analysis of the data, four participant responses emerged: engaging with the storybook without explicitly exploring global justice issues; exploring the concept of fairness; using existing intercultural, environmental or development education resources (aimed at young children or modified from those aimed at older children); and teaching about Kenya.

\section{No Explicit Global Justice Exploration}

Several of the participating educators used the storybook as a stimulus for cross curricular work which encouraged engagement with the book and supported comprehension. However, they did not explicitly explore issues of global justice. For 
example, several teachers made pancakes in the class, as Mama Panya does in the book, made props relating to the book or did art activities responding to images in the book. Two of the teachers applied the Building Bridges of Understanding methodology (Gleeson et al, 2010) for improving comprehension supporting literacy work. ${ }^{6}$

\section{Exploring Issues of Fairness}

Over half of the participants had explicitly explored the issue of fairness in an immediate or wider context. The learning experiences recorded reflected the centrality of the concept of fairness to early childhood education and showed educators' comfort in exploring the concept in both local and global contexts. However, the results also raised concerns that, in exploring fairness, educators might reaffirm a deficit model of development and impose dominant value systems.

Many of the participating educators recorded that they had simulated fair and unfair scenarios to help children identify fair/unfair outcomes. Examples recorded suggested a range of approaches on the part of the educators, from those who facilitated more open and critical dialogue to more superficial and contrived considerations. One participant pre-school educator, for example, gave two children new toys and took one back before the child had had a chance to play with it. The children then discussed this experience. Another teacher divided up pancakes unevenly, facilitating discussion about sharing and fairness.

Where participants explored the concept of fairness in relation to the storybook, there was evidence that this process privileged an approach to development, in which the children's 'western' and familiar circumstances were the desired outcome for all people globally. One participant educator described how

'Children asked why the ladies carried stuff on their heads. Another child said because it is very heavy. I asked when we go to the market do we carry things on our head. They all said no we carry things in bags and put them in the boot of the car. I ask is it fair that they carry things on their head and we put our bags in cars. They all say no they should get cars. How can they get cars. What would they need. They all say money. How could they get money. Ask their daddy.' (Teacher: Junior Infant class)

While the teacher is infusing a language of justice or 'fairness' into the discussion around similarities and differences between the experiences presented in the storybooks and the children's own experiences, this language is intently values-driven and serves to reinforce a conventional model of development which sees developing countries as lacking or backward and developed countries as aspirational. It does not encourage critical engagement with the concept of fairness, the causes of poverty or the dominant model of development. It diminishes difference rather than encouraging openness to and appreciation of it. This comparison between shopping with bags and cars and shopping with baskets raises many complex global justice issues, particularly regarding the environment (infrastructural development, carbon emissions, waste, community/urban development to name but a few). 
Automatically labelling the 'lack' of cars as unfair prevents more open exploration of alternative lifestyles, critical engagement with development and reinforces the binaries of them and us, rich and poor. These findings raise the question of how to explore global inequality and lack of resources without perpetuating particular dominant theories of development.

\section{Using Existing Development or Intercultural Resources}

Several of the participant educators drew on two existing educational resources: an early childhood intercultural education pack and an early childhood pack looking at water in developing world contexts. With regard to use of the water pack, here participants approached the storybook with an environmental focus and bridged learning from the storybook with learning using the water resource. Several of the participant educators described using a picture of a jerrycan and discussing the experience of having to carry water a long distance.

In the focus groups a few of the participants suggested drawing on development education activities designed for older children, particularly those related to trade and fairtrade. This discussion raised the problematic concept of developing early childhood learning experiences by 'simplifying' activities designed for older children and highlights the need to establish a rubric for exploring global justice issues through early childhood pedagogy.

\section{Further Work on Kenya and Africa}

Most of the participant educators included some activities looking at the location of, or further information on, Kenya. Two of the participants asked their children to make passports and enact a plane journey to Kenya. Several of the participants located Ireland and Kenya on maps. Others looked at Kenya's wildlife and aspect of Kenyan culture, including foods and games. These activities support interest and engagement with Kenya; however, it is questionable how much they build competency in the area of global citizenship. The focus on culture and geographical landscape remains in safe territory as against the introduction of more justicerelated concerns (Davies et al, 1999). While the emphasis on differences, in terms of animals and games for example, provides more in-depth exploration of the context in which the story is set, it could result in the exoticisation of Kenya.

Participant educators were divided on whether or not experiences of poverty in Kenya should be explored with the children. One participant educator stated,

'the book was so happy and colourful. I didn't want to then talk about poverty, I didn't want to upset them.' (Teacher: Junior Infant class)

Another educator on the other hand, provided information on Kenya which emphasised the poverty experienced in the country. The quote below was representative of much of the pupils' work submitted by this participant. 
'In Kenya some people are very poor. They have to build their school. They even have to clean their school. They have to walk miles to get there. The Kids are smart.' (Pupil: Senior Infant class)

Overall, the work suggests an essentialist view of poverty in Kenya and raises concerns about reinforcing stereotypes. It calls for reflection on how to problematise and complexify children's growing impressions of Kenya.

\section{Results of Phase Three}

The participant educators involved with the third phase of the project were introduced to the draft programme and asked to report on their experience of using the programme in their early childhood educational setting. An analysis of the focus group meetings, the structured diaries and the pupil work provided, suggests that participant educators had each used the programme differently, responding to the individual needs and experiences of their children. It further suggested that in general children had connected with the story, the characters and with Kenya and had been encouraged to think more critically about concepts such as race, fairness and similarities and differences between lifestyles.

\section{Different Responses to the Draft Programme}

The draft education programme provided to all participant educators did not distinguish between different educational settings, for example between primary school classes and pre-school educational settings. As was encouraged and expected, the participating educators approached the materials differently and adapted the materials to suit their contexts. From the data provided, the majority of educators appeared to have delivered most of the learning experiences included in the programme in a way which tested the methodology developed and met with the key learning objectives. For example the programme suggested building an understanding of the location of Kenya by using a poem which travelled the landscapes between Ireland and Kenya. One educator in a multigrade primary school setting described how she put the pictures (of the different landscapes) on the interactive white board and explored the journey using the poem, maps and sequencing. Another educator in a creche setting used the poem as part of a movement activity in the creche yard, where the children acted travelling through each landscape and discussed alternative ways to travel. While both educators applied the suggested learning experience to their own context, they, nonetheless, tested the poem and landscapes as a method for teaching about the wider world, exploring distance and projecting the diversity and expanse of parts of Africa. The results provided suggest that the programme is not overly dependent on the teacher's capacity in global citizenship education to meet its learning objectives.

The data collected here support the findings from phase one of the research, in indicating children's developing capacity to articulate and discuss global justice issues within the ages considered. Older children more than younger children were reported to be able to engage in and learn through discussion around the issues 
raised. Younger children, on the other hand, were reported to have responded to the issues raised through drama, art and play. One educator described how:

'The children loved the Kenyan play corner. I wasn't sure if they really got the story and then I saw them holding a stick like Mama Panya and I could see that they had got it. They couldn't necessarily discuss it but you could tell they had got it from the way they played it out.' (Educator: Preschool setting)

The findings support Brunerian theory with regard to children's emergent capacities to engage with complex ideas at a level appropriate to their development (Bruner, 1960).

\section{Connecting with People and Places}

The results of phase three of the research indicated a high level of emotional connection across the research settings, between the children and the characters in the materials. The following quote is indicative of the nature of the responses.

'I enjoyed building the relationship between Adika and the children, emphasising the similarities and differences between them. They could relate to him as their friend.' (Educator: Pre-school setting)

These findings reflect a relationship established between the children and the characters which is characterised by equality and respect. There was no evidence of children perceiving the characters as being 'essentially different' but of being interested both by what they had in common and by how their lives differed. Several of the participant educators stated that children from different minority backgrounds recognised specific connections between their lives and the Kenyan lives presented. This included children with parents or grandparents from African countries, from other countries and traveller children. These reactions raise questions concerning the self-identity of the minority children involved and suggest the potential for the programme to support recognition of diversity within the educational setting in which it is delivered.

Most of the children, particularly the younger children, did not appear to identify the lifestyles reflected in the materials as inferior to their own. One child was reported as stating that Adika's house was bigger than hers; another educator reported that all her children wanted to go to Kenya and several participant educators noted that the children did not recognise poverty in the photographs of urban Kenya. By contrast, several of the participant educators recorded their own perceptions of the images as potentially 'upsetting' for young children. This discrepancy suggests that in general, the young children participating in the programme remained open to alternative values systems regarding lifestyles, development and 'underdevelopment'. It also highlights the delicate balance that needs to be maintained between enabling children's growing understanding of poverty in a global context while guarding against a deficit and essentialised view of developing countries. 


\section{Moving Away from a Language of Deficit and Poverty}

The language of poverty or deficit reflected in phase two of the research process was markedly reduced in the results of phase three. The data collected suggested that, while challenges faced by the characters had been raised, children's impressions of Kenya and the lives explored were predominantly happy ones. One participant educator, representative of much of the data collected, reflected that:

'What I really loved about this activity was that all the children were really looking forward to their journey to Kenya having prior knowledge of Adika and the story... they thought he was a happy boy who had a good mummy, nice friend and plenty of pets.' (Educator: Pre-school setting).

The programme explored the lives of children living in impoverished circumstances in Kenya. It included consideration of aspects of these children's lives that indicated potential vulnerabilities, including the foods they ate, where their foods came from, their homes and their daily routines. However the programme's approach, which avoided a discourse of deficit or need, appears to have resulted in children forming predominantly positive conceptions of life in Kenya. The findings suggest also that there is an ongoing tension between promoting the construction of more complex and diverse discourses around people's lives in developing countries and guarding against an idealised view of life in contexts characterised by structural inequality. The challenge is to avoid characterising people in African countries as essentially poor, while adequately acknowledging the impact of poverty.

There was evidence of children's learning being influenced by dominant social attitudes outside of the educational setting, characterising people in Africa as unhappy and poor. One participant educator commented that:

'I sent children home with speech bubbles to fill in relating to the photos. You could see that the influence from home produced negative stereotypes despite the fact that children had not come up with any of these during discussion in class, for example they said I am sad or poor or need money.' (Teacher: Senior Infant class)

These findings re-affirm the results of phase one of the research, which reflect the extent to which children's impressions of the wider world are constructed by learning outside of the classroom and of the pre-dominance of stereotypical, essentialist conceptions of Africa, epitomised in charitable fundraising campaigns, in the wider community.

\section{Critical Engagement and Perspective Consciousness}

The programme suggests using the story, a puppet and teacher-in-role methodology to explore alternative perspectives. For example, educators used the puppet to question the children about everyday aspects of their lives. The research indicated that these methods encouraged children to reflect on their lifestyles, as well as on concepts such as race and culture. Many of the participant educators commented on the interest the children had shown in how things they took for granted could be unfamiliar to others. Questions the programme had instigated from the children 
including: how milk gets into the carton, what was powered by electricity, how electricity was made and how you get money. The alternative perspectives explored in the programme appeared to have provided opportunities for educators to facilitate children's analysis of their own lives, environments and attitudes.

The programme supported children's understanding of the daily life of two child characters living in Kenya, a boy from a small-holder farming community and a girl living in an unplanned settlement outside Nairobi. There was evidence from the research findings that children engaged with the detail of the lives presented, making specific observations about their homes and communities and developing a more nuanced understanding of the multiple contexts of people's lives in Kenya. Such understanding provides a foundation of knowledge from which to scaffold critical engagement with global justice related issues.

\section{Discussion}

The research conducted provides strong evidence that young children are building conceptions of global and justice issues through their lives at home, through the media and in educational settings. This global learning, which may be incidental and unbalanced, highlights the need to introduce global citizenship into early childhood education. However the research also indicates particular concerns that can arise when global or justice issues are explored with young children. The educational programme arising from the research identifies suitable content and pedagogy for early childhood global citizenship education. It suggests that connecting young children emotionally, geographically and intellectually with people and places in developing countries supports a more critical, complex and engaged approach to global learning.

\section{Exploring Fairness as a Global Citizenship Concept}

The results of this research reflect the wider literature which suggests that children's thinking around fairness develops considerably from pre-school age (Killen, Breton Ferguson and Handler, 1994; Killen and Smetana; 1999; Tisak 1995 cited in Killen $e t$ $a l$, 2001). Participant educators, echoing Aistear (NCCA, 2009), identified the concept of fairness as a integral part of early childhood education and recognised the parallels between the daily concerns of small children and global issues, discussed by Fountain (1990).

While the concept of fairness might be acknowledged as an appropriate global citizenship theme for early childhood education (Fountain, 1990; Ramsey, 2008b, Oxfam, 2006), the question remains as to how it can be explored to best support children's development as global 'justice-orientated' citizens (Westheimer and Kahne, 2004). As the research highlights, exploring 'fairness' in a global context risks reinforcing prevailing social attitudes, where labelling scenarios as fair and unfair is used to privilege and perpetuate a deficit model of development. 
One recommendation arising from the research is that the concept of fairness be explored as it arises incidentally in the classroom or pre-school. Where educators encouraged further reflection on fairness as opportunity presented itself in the course of the day, learning was perceived to be more meaningful than where scenarios were simulated or contrived. From a global citizenship education perspective, children's exploration and articulation around the concept of fairness as it applies to their immediate context exercises political skills and social activism (Fisher, 2005; Hicks, 2003; Fountain, 1990; McCloskey, 2011), thereby developing citizenship.

On another level, the research highlights the importance of providing open-ended challenges for children. As against labelling one situation as fair and another as unfair, the research supports the educational value in children being encouraged to work through justice-related scenarios where the resolutions are multiple. The programme developed from and tested in the research suggests using drama and introducing scenarios which enable the children to explore different responses and outcomes. Scenarios suggested included those likely to be familiar to the children and those reflecting global concerns, for example: unequal buying power disrupting local markets, migration and food insecurity. Asking children to evaluate and respond to these situations enacts the Freirean dynamic of reflection and action (Freire, 1994; McCloskey, 2011). It locates children as agents in their own learning and as citizens rather than recipients of knowledge or citizens-in-the-making. The learning experience becomes transformative and empowering as children arrive at behaviours they consider fair rather than just evaluating others' behaviour. The pedagogy can be considered 'critical' (Andreotti, 2006) in that it provides spaces to analyse and experiment without telling learners what to think. Table 3 below outlines the challenges and opportunities which key themes present in an early childhood context, and suggests learning experiences derived from the research that are potentially transformative.

\section{Scaffolding an Understanding of Global Poverty}

The attitudes of the participant educators towards teaching children about global poverty was reflective of the wider debate about children's perceived readiness to deal with social justice issues (Robinson and Jones Diaz, 2009 and Kelly and Brooks, 2009). As is discussed above, several of the participant educators 'didn't want to upset' the children or, in regard to the draft programme, take away from the colourful and happy portrayal of Kenyan life presented. Their concern, that poverty related issues are inappropriate for young children, reflects the discourse of vulnerability and innocence, characteristic of a modernist perspective of childhood (Kelly and Brooks, 2009; Robinson and Jones Diaz, 2009). Other participant educators however introduced poverty into their teaching on their own initiative. Where educators did so there was some evidence to suggest that the approach tended to govern children's 
Table 3: Overview of Challenges, Opportunities and Suggestions for a Global Justice Early Childhood Education Programme

\begin{tabular}{|c|c|c|c|}
\hline Themes & Challenges & Opportunities & Learning Experiences \\
\hline \multirow[t]{2}{*}{ Fairness } & $\begin{array}{l}\text { Labelling poverty as } \\
\text { unfair can reinforce } \\
\text { traditional models of } \\
\text { development without } \\
\text { critical analysis. }\end{array}$ & $\begin{array}{l}\text { Acknowledged as a key } \\
\text { aspect of early childhood } \\
\text { education. }\end{array}$ & $\begin{array}{l}\text { Support children's emergent } \\
\text { understanding through open-ended } \\
\text { explorations of fair/ unfair scenarios in } \\
\text { immediate, local and global contexts. }\end{array}$ \\
\hline & & & $\begin{array}{l}\text { Enable children to evaluate possible } \\
\text { responses to justice scenarios. }\end{array}$ \\
\hline Poverty & $\begin{array}{l}\text { Can reinforce } \\
\text { stereotypes and } \\
\text { essentialist views of } \\
\text { developing countries. }\end{array}$ & $\begin{array}{l}\text { Can develop } \\
\text { understanding and } \\
\text { knowledge about the } \\
\text { wider world and how } \\
\text { people live. }\end{array}$ & $\begin{array}{l}\text { Explore multiple aspects of the lives } \\
\text { and experiences of individuals living in } \\
\text { a impoverished situations for example: } \\
\text { foods, homes, daily life. This provides } \\
\text { multifacted impressions of the } \\
\text { experiences of people living in } \\
\text { impoverished situation in developing } \\
\text { countries. }\end{array}$ \\
\hline \multirow[t]{3}{*}{$\begin{array}{l}\text { Empathy and } \\
\text { Perspective } \\
\text { Consciousness }\end{array}$} & $\begin{array}{l}\text { Risk of empathy } \\
\text { reinforcing binaries of } \\
\text { them and us or negating } \\
\text { differences between } \\
\text { 'reader' and 'other' and } \\
\text { social forces }\end{array}$ & $\begin{array}{l}\text { Engagement of young } \\
\text { children with characters } \\
\text { transcends racial } \\
\text { hierarchies and ethnic } \\
\text { and geographical } \\
\text { boundaries and develops }\end{array}$ & $\begin{array}{l}\text { Exploring different characters' } \\
\text { thoughts and concerns in picture } \\
\text { books and the children's own } \\
\text { books and the children's own } \\
\text { positionality. }\end{array}$ \\
\hline & underpinning differences. & care and attachment. & $\begin{array}{l}\text { Playing out scenes from the books } \\
\text { and photographs. }\end{array}$ \\
\hline & & & Advising the puppet character. \\
\hline $\begin{array}{l}\text { Learning about the } \\
\text { wider world, its } \\
\text { people and places }\end{array}$ & $\begin{array}{l}\text { Reinforce stereotypical } \\
\text { impressions of } \\
\text { developing countries. } \\
\text { Use inappropriate } \\
\text { pedagogy for early } \\
\text { childhood education. }\end{array}$ & $\begin{array}{l}\text { While assimilating } \\
\text { predominant social } \\
\text { attitudes, young children } \\
\text { demonstrate more open } \\
\text { value systems regarding } \\
\text { poverty and development. }\end{array}$ & $\begin{array}{l}\text { Explore the diverse and extensive } \\
\text { landscapes between children's } \\
\text { country of residence and place that is } \\
\text { the subject of study. } \\
\text { Reflect the diversity of people and } \\
\text { landscapes in developing countries. }\end{array}$ \\
\hline
\end{tabular}

perceptions of Kenya and served to reinforce stereotypical essentialist views of African poverty.

While the inclusion of global poverty in early childhood education may prove controversial and problematic, it can also be seen as integral to building an understanding of the wider world, global justice and global citizenship. Furthermore, as the first phase of the research indicates, young children are already developing perceptions of global poverty from the media and fundraising campaigns. This supports the inclusion of learning about global poverty in early childhood citizenship education programmes as necessary to deepen and complexify the messages children receive from outside the classroom or pre-school.

Testing Bruner's assertion that all subjects can be taught to any child, this research process sought to arrive at suggestions for exploring global poverty with children in ways that are 'intellectually honest' (Bruner, 1960:33), age appropriate, avoid essentialist views of poverty and support children's developing understanding of how the 
wider world works. The programme, arising from the research, suggests learning experiences which build an understanding of the daily experiences of some people living in vulnerable circumstances in developing countries. The approach avoids a language of poverty and need and provides a deeper understanding of how different people live, which can then facilitate more complex exploration of the justice issues which threaten people's livelihoods. Issues such as access to water, electricity, food and adequate housing are problematised through story-based activities. For example, one of the learning experiences, developed from and tested in the research, encourages children to recognise the dependency on local sources of food, experienced by some of the characters portrayed in the materials. It presents images of Kenya as fertile and fruitful, which problematises conceptions, evident in the research, of Africa as a barren continent and raises questions regarding the causes of food insecurity. In exploring this self-sufficiency, children are better placed, at a later stage, to understand the vulnerability of small-holder farmers and some of the causal relations that underpin chronic and acute hunger, as well as to critically review the implications of historic patterns of consumption characteristic of the global North. This approach supports a growing understanding of the world in which we live and begins an education in how the world works (Bryan et al, 2009; Oxfam, 1997).

The research highlights not only differing approaches of educators to children and childhood but also the tendency to regard learning about people experiencing poverty as necessarily upsetting. Participant educators, who at the outset were uncomfortable about including global poverty in their teaching, did not regard exploring with the children different people's sources of food, homes or daily tasks as problematic.

\section{Starting Beyond Binaries and Racial Categorisation}

This research reflects previous findings, in suggesting that young children readily absorb prevailing social attitudes and prejudice (Ruble and Martin, 1998; Connolly, 1998; Killen et al, 2001). The considerable extent to which children as young as three are forming impressions of 'Africa' and African people from images in the media and in fund-raising campaigns was evident in the findings from the first phase of the research. Furthermore, the possibility of these stereotypical impressions being reaffirmed in early childhood educational settings (Derman-Sparks and Phillips, 1997) was highlighted by phase two of the research. Even when educators deliberately sought to provide a more critical and diverse perspective on, in this case, Kenya, as in the third phase of the research process, there was evidence that children's learning continued to be influenced by prevailing attitudes held at home and elsewhere. The research highlights the importance, documented elsewhere (Ramsey, 2008b) of ensuring stereotypes are not reinforced. 
The programme explores the lives and environments of people living in Ireland and Kenya without constructing binaries or simplistic categorisations. For example, the learning experiences included in the programme seek to emphasise, through art and image work, both the plurality of identities and the idea of multiple identities, exploring the similarities and differences between and within the countries in question. The programme, focussing on global justice, does not deal explicitly with the issue of race. However, it does not attempt to negate or avoid racial differences and encourages educators to respond to racial attitudes as they arise. Where educators felt comfortable in examining racial prejudice and difference, there was evidence of dialogue between children and educators examining more critically issues of race and equality. The findings support suggestions that children of early primary-school age are able to participate in and contribute to discussion relating to issues of race and diversity (Husband, 2010), with children raising issues about their own and others' ethnic and racial identities.

\section{Building Empathy and Perspective Consciousness as a Tool to Understanding and Equality}

The findings from the research suggest that the approach adopted by the programme supported children's engagement with cultural and racial difference without recourse to, or affirmation of, stereotypes or a discourse of 'them and us'. Concerns regarding a tendency for multi-cultural education to be superficial, to exoticise difference and to reinforce bias (Robinson et al, 2009; Ramsey, 2008b), were far less apparent where participating educators used the suggested programme in phase three of the research than in phase two. Children involved in phase three of the research were encouraged to actively empathise with the characters in the materials, pretending to be them in a Kenyan market play corner and drama activity, verbalising the character's thoughts at different points of their story, advising the Adika puppet on challenges he raised. Through these learning experiences the children were reported to engage with the characters on an individual level, rather than to build generalised conceptions. They were reported to relate to the characters as 'friends' and 'role models'.

These findings suggest that the programme subverted identified tendencies amongst young children to adopt racial hierarchies that correspond with adult prejudices (Siraj-Blatchford, 1994) and to display negative behaviour towards children from different racial backgrounds (Glover, 1991 cited in Robinson and Jones Diaz, 2009).

The research supports Morgan's contention that teaching young children to have multiple perspectives 'is likely to reduce problems involving prejudice or discrimination and is an important component of early childhood education' (Morgan, 2009). Fostering empathy has long been recognised as contributing to a more socially just world (Dewy and Rosenblatt quoted in Boler, 1997) and has been identi- 
fied as appropriate for early global citizenship education (Brophy and Alleman, 2008 and Oxfam, 2006). While 'passive empathy' has been criticised for not going far enough in terms of appreciating the social forces governing the relationship between the reader and the 'other' (Boler, 1997), the empathy constructed between the children and the characters appeared to support engagement across racial, cultural and geographical boundaries.

\section{Conclusion}

Exploring the culpability or privilege of learners in global poverty and injustice when those learners are young children, raises questions of ethics as well as plausibility, especially when children themselves could be regarded as a marginalised group (Alderson, 1999). A critical approach to global citizenship in early childhood education, therefore, needs to engage with the emerging capacities of young children and the particular context of early childhood education settings. The Just Children programme was developed though an iterative process of research, practice and critical reflection. This allowed the resource development team to identify points of contradiction and possible tensions in realising a global citizenship education programme for early childhood contexts. The programme seeks to build an engagement amongst children living in Ireland with people living in a developing country, in this case Kenya. It promotes an understanding of aspects of the lives of some people living in Kenya and of the connections (geographic and economic) between Kenya and Ireland. It encourages young children to articulate their responses to injustice in their immediate and more remote contexts and to explore possible resolutions or reactions to that injustice in an open-ended way. While the programme does not explicitly consider economic, racial or cultural power structures, it provides a starting point for the development of a more complex, critical and nuanced global understanding as children progress in the context of primary education and beyond.

Rowan Oberman is Programme Coordinator of the Education for a Just World Partnership and a lecturer in Development, Intercultural, Human Rights and Citizenship Education at St Patrick's College, Drumcondra. Rowan has considerable experience in global citizenship education in both formal and informal education contexts. She is also a qualified Barrister with particular expertise in human rights and family law.Rowan.Oberman@spd.dcu.ie

Fionnuala Waldron is Dean of Education in St Patrick's College, Drumcondra, and Chair of the Centre for Human Rights and Citizenship Education. Fionnuala worked for many years as a primary teacher before becoming a teacher educator. Her areas of teaching and research include history education, human rights education and global citizenship. Recent publications include Waldron, F., and Ruane, B. (Eds.) (2010). Human Rights Education: Reflections on theory and practice. Dublin: Liffey.

56 International Journal of Development Education and Global Learning 4(1) 2012 
Sheila Dillon has been Education Officer with Trócaire, with particular responsibility for early childhood and primary education, for many years. She began her career as a primary teacher and has taught in Ireland and Kenya. She is currently Co-ordinator of Happy Talk, an early years intervention project supporting language development in disadvantaged areas of Cork.

\section{Notes}

1 St Patrick's College specialises in teacher education at primary level and is a college of Dublin City University. 2 Piaget's theory is based on the notion 'that all children reach certain cognitive development stages' (that are biologically predetermined) that 'correlate' with specific chronological ages. The process is linear, begins at birth and continues until adulthood (Robinson and Jones Díaz, 2009:6). Piagetian theory ignores children's social world (Van Ausdale and Feagin, 1996). On the other hand theorists such as Vygotsky (1986) and Donaldson (1978) locate children 'in a social world in which interactions are the source of mental functioning and meanings for social concepts' (Peterson and McCabe, 1994:780).

3 In October 2009, the National Council for Curriculum and Assessment (NCCA) in Ireland published Aistear: the Early Childhood Curriculum Framework. Aistear is designed to be used in all settings in which children from birth to six are educated in Ireland including children's own homes, child-minding settings, full and part-time daycare settings, sessional services as well as infant classes in primary schools. The Framework uses four interconnected themes to describe the content of children's learning and development: Well-being, Identity and Belonging, Communicating, and Exploring and Thinking. In infant class settings it is used in conjunction with the Primary Curriculum to which it has both implicit and explicit links.

4 Junior and Senior Infant classes in Ireland are the first two years of primary schooling. Ordinarily children aged between four years and six years attend these classes. Legislation requires children to attend school from the age of six; however, in practice nearly all five-year-olds and about half of four-year-olds attend Primary school. Preschool services vary considerably from home childcare, to full and part-time day care, to playschool. The Early Childhood Care and Education Scheme provides for a year of free early care and education for children of preschool age and is widely subscribed to.

5 This included Aistear: The Early Childhood Curriculum Framework and the National Primary Curriculum of the Republic of Ireland and of Northern Ireland.

6 Building Bridges of Understanding is an approach to the teaching of comprehension. The methodology was recently developed from research conducted in Ireland.

\section{References}

Alderson, P. (1999) Human rights and democracy in schools do they mean more than 'picking up litter and not killing whales'? International Journal of Children's Rights 7:185-205.

Andreotti, V. (2006) Soft Versus Critical Global Citizenship Education. Policy and Practice: A Development Education Review 3(4):40-51.

Boler, M. (1997) The Risk of Empathy: Interrogating Multiculturism's Gaze. Cultural Studies, 11(2):253-273.

Bracken, M. and Bryan, A. (2010) The Reflective Practitioner Model as a Means of Evaluating Development Education Practice: Post-Primary Teacher's Self Reflections on 'Doing' Development Education. Policy and Practice: A Development Education Review 11 (2):22-41.

Brooker, L. (2006) From Home to Home Corner: Observing Children's Identity-Maintenance in Early Childhood Settings. Children and Society 20:116-127.

Brophy, J. and Alleman, J. (2008) Early Elementary Social Studies. In L. Levstik and C. Tyson (ed) Handbook of Research in Social Studies Education. New York: Routledge.

Brown, C. and Bigler, R. (2005) Children's Perceptions of Discrimination: A Developmental Model. Child Development 76(3):533-553

Bruner, J. (1960) The Process of Education. Cambridge: Harvard University Press.

Bryan, A. (2008) Researching, and Searching for, International Development in the Formal Curriculum: Towards a Post-Colonial Conceptual Framework. Policy and Practice: A Development Education Review, 7(5):62-75.

Bryan, A, Clarke, M. and Drudy, S. (2009) Social Justice Education in Initial Teacher Education: a Cross Border Perspective. www.scotens.org/?p=16. Last accessed: 18/11/11. 
Case, R. (1993) Key Elements of a Global Perspective. Social Education 57(6):318-325.

Chamberlin, M. and Chamberlin, R. (2005) Mama Panya's Pancakes: A Village Tale from Kenya. Bath: Barefoot Books.

Chafel, J.A. (1997) Children's Views of Poverty: A Review of Research and Implications for Teaching. The Educational Forum, 61(4):360-371.

Chafel, J.A., Flint, A., Hammel, J., Pomeroy, K.H. (2007) Young Children, Social Issues and Critical Literacy: Stories of Teachers and Researchers. Young Children 62(1):73-81.

Clark, A. and Moss, P. (2001) Listening to Young Children: The Mosaic Approach. London: National Children's Bureau Enterprises Ltd.

Connolly, P. (1998) Racism, Gender Identities and Young Children. London: Routledge.

Connolly, P. and Hosken, K. (2006) The general and specific effects of educational programmes aimed at promoting awareness of and respect for diversity among young children. International Journal of Early Years Education, 14(2): 107-126.

Davies, I., Gregory, I., and Riley, S. (1999) Good Citizenship and Educational Provision. London: Falmer.

Davies, L. (2006) Global Citizenship: abstraction or framework for action? Educational Review 58(1):5-25.

Derman-Sparks, L. and Phillips, C.B. (1997) Teaching and Learning Anti- Racism: A Developmental Approach. New York: Teachers College Press.

Devine, D. (2003) Children, Power and Schooling: How Childhood is Structured in the Primary School. Stoke-onTrent: Trentham Books.

Fiedler, M., Gill, B., O'Neill, C. and Pérez Piñán, A. (2008) Global Dimensions A Guide to Good Practice in Development Education and Intercultural Education for Teacher Educators. Dublin: DICE.

Fisher, R. (2005) Teaching Children to Think (2nd edition). Cheltenham: Stanley Thornes Publishers Ltd.

Fountain, S. (1990) Learning Together Global Education 4-7. Cheltenham: Stanley Thornes Publishers Ltd.

Freire, P. (1994) Pedagogy of the Oppressed. New York: Continuum.

Glaser, B. G. and Strauss, A.L. (1967) The Discovery of Grounded Theory: Strategies for Qualitative Research. Chicago: Aldine Publishing Company.

Gleeson, M., Courtney, A. and Bowe, T. (2009) Building Bridges of Understanding: Teacher's Manual. Limerick: Curriculum Development Unit, Mary Immaculate College.

Hicks, D. (2003) Thirty Years of Global Education: a reminder of key principles and precedents. Educational Review 55(3):265-275.

Husband, T. (2010) He's Too Young to Learn About That Stuff: Anti-Racist Pedagogy and Early Childhood Social Studies. Social Studies Research and Practice 5(2):61-75.

Hong, Y (2003) An Ethnographic Study of Korean Kindergartners' Reasoning during Group Moral Discussions. Early Childhood Education Journal 30(3):151-156

Kelly, D.M. and Brooks, M. (2009) How Young is Too Young? Exploring Beginning Teachers' Assumptions about Young Children and Teaching for Social Justice. Equity and Excellence in Education 42(2):202-216.

Killen, M., Pisacane, K., Lee-Kim, J. and Ardila-Rey, A. (2001) Fairness or Stereotypes? Young Children's Priorities When Evaluating Group Exclusion and Inclusion. Developmental Psychology 37(5):587-596.

Krause, J. (2010) Development Education Watch: European Development Education Monitoring Report http:// www.coe.int/t/dg4/nscentre/ge/DE_Watch.pdf. Last accessed: 18/11/11

McCloskey, S. (2011) Development Education and Social Change: The role of the development sector. Policy and Practice: A Development Education Review 12(4):32-46.

Morgan, H. (2009) Picture Book Biographies for Young Children: A Way to Teach Multiple Perspectives. Early Childhood Education Journal 37:219-227.

Myers, G. (1998) Displaying Opinion: Topics and disagreements in focus groups. Language in Society 27: 85-111. National Council for Curriculum and Assessment (2009) Aistear: The Early Childhood Curriculum Framework. http://www.ncca.biz/Aistear/. Last accessed 24/11/11.

Oxfam (1997) A Curriculum for Global Citizenship. Oxford: Oxfam.

Oxfam (2006) Education for Global Citizenship: A Guide for Schools. Oxford: Oxfam.

58 International Journal of Development Education and Global Learning 4(1) 2012 
Peterson, C. and McCabe, A. (1994) A Social Interactionist Account of Developing Decontextualized Narrative Skill. Developmental Psychology 30(6):937-948

Piaget,J. (1932) Le Jugement Moral Chez L'enfant [The Moral Judgement of the Child]. Paris: Alcon .

Pike, G. and Selby, D. (2000) In the Global Classroom 2. Ontario: Pippin Publishing.

Ramsey, P.G. (2008a) Children's Responses to Differences. NHSA Dialog, 11 (4), :225-237.

Ramsey, P.G. (2008b) Multicultural Education and Head Start: Empowering Young Children. NHSA Dialog, 11(4):191-205.

Regan, C. (2006) Describing ... Understanding ...Challenging ... The Story of Human Development in Today's World. http://www.irishaid.gov.ie/Uploads/rish\%20Aid\%20and\%20Development\%20Education.pdf. Last accessed 18/11/11.

Robinson, K.H. and Jones Díaz, C. (2009) Diversity and Difference in Early Childhood Education, Issues for theory and practice. Berkshire: Open University Press.

Ruble, D.N. and Martin, C.L. (1998) Gender development. In W. Damon and N. Eisenberg (ed) Handbook of Child Psychology: Vol 3. Social, emotional, and personality development. New York: Wiley

Siraj-Blatchford, I. (1994) The Early Years: Laying the Foundation for Racial Equality. Staffordshire: Trentham Books.

Van Ausdale, D. and Feagin, J.R. (1996) Using Racial and Ethnic Concepts: The Critical Case of Very Young Children. American Sociological Review 61(5):779-793.

Westheimer , J. and Kahne, J. (2004). What Kind of Citizen? The politics of educating for democracy. American Educational Research Journal 41(2):237-269.

Wibeck, V., Dahlgren, M. A., and Oberg, G. (2007) Learning in Focus Groups: An analytical dimension for enhancing focus group research. Qualitative Research 7(2):249-267. 


\section{Appendix A: About the Just Children Resource}

The Just Children Story Sack was published in April 2011 by Education for a Just World: An Initiative of Trócaire and the Centre for Human Rights and Citizenship Education, St Patrick's College, Drumcondra. The Story Sack contains: the Programme handbook, the Mama Panya's Pancakes storybook, eight photographs of Cecelia- a girl living in urban Kenya, a hand puppet, a CD and four posters taken from the storybook. For additional information about the Story Sack see www.trocaire.org/educationforajustworld. The Story Sack is available from Trócaire, Maynooth, County Kildare.

The Programme contains 12 learning experiences for introducing global citizenship into early childhood education using the resources in the Story Sack.

\section{Content of the Just Children Story Sack Programme}

\begin{tabular}{|c|c|c|}
\hline Module & Learning Experience & Issues Explored \\
\hline \multirow[t]{3}{*}{ Near and Far } & $\begin{array}{l}\text { Using a poem to travel from Ireland } \\
\text { to Kenya }\end{array}$ & $\begin{array}{l}\text { Wider world- distance, landscapes and } \\
\text { and diversity }\end{array}$ \\
\hline & Meeting the Adika puppet & $\begin{array}{l}\text { Perspective consciousness, similarity and } \\
\text { difference }\end{array}$ \\
\hline & $\begin{array}{l}\text { Making props and costumes in the } \\
\text { storybook }\end{array}$ & Empathy and diversity \\
\hline \multirow[t]{3}{*}{ Another Perspective } & $\begin{array}{l}\text { Creating a life size Adika and mapping } \\
\text { his journey to the market }\end{array}$ & $\begin{array}{l}\text { Story comprehension, economic vulnerability, } \\
\text { perspective consciousness }\end{array}$ \\
\hline & $\begin{array}{l}\text { Creating and playing in a play corner } \\
\text { depicting the Kenyan market scene }\end{array}$ & Empathy, similarity and difference \\
\hline & $\begin{array}{l}\text { Meeting Cecelia and exploring her } \\
\text { photographs }\end{array}$ & Diversity, urbanisation, housing \\
\hline \multirow[t]{3}{*}{ Living with Poverty } & $\begin{array}{l}\text { Investigating how food is produced } \\
\text { using orienteering and scavenger hunts }\end{array}$ & Small holder farmers, food vulnerability \\
\hline & Exploring daily chores & Children's lives, education \\
\hline & Making and comparing homes & $\begin{array}{l}\text { Access to facilities including: electricity, water } \\
\text { and adequate housing }\end{array}$ \\
\hline \multirow[t]{3}{*}{$\begin{array}{l}\text { Exploring Fairness } \\
\text { and Interdependence }\end{array}$} & $\begin{array}{l}\text { Discussing fairness and responses to } \\
\text { justice scenarios }\end{array}$ & Fairness and activism \\
\hline & $\begin{array}{l}\text { Looking at fairness in the Kenyan market } \\
\text { scene using teacher in role drama } \\
\text { methodology }\end{array}$ & $\begin{array}{l}\text { Fairness and justice, migration, } \\
\text { international trade, inequality, land ownership }\end{array}$ \\
\hline & $\begin{array}{l}\text { Using a poem and children's senses to } \\
\text { look at foods from Kenya consumed in } \\
\text { Ireland }\end{array}$ & Globalisation, trade, interdependence \\
\hline
\end{tabular}

60 International Journal of Development Education and Global Learning 4(1) 2012 